\title{
Peningkatan Hasil Belajar Passing Atas Bola Voli, Siswa SMK Melalui Variasi Pembelajaran
}

\author{
Sandy Yudha Sinurat ${ }^{1}$, Sabaruddin Yunis Bangun ${ }^{2}$ \\ Fakultas Ilmu Keolahragaan, Universitas Negeri Medan \\ unisbgn@unimed.ac.id
}

\begin{abstract}
ABSTRAK
Penelitian ini dilakukan bertujuan untuk mengetahui sejauh mana peningkatan hasil belajar Passing atas melalui variasi pembelajaran pada siswa kelas XI SMK Parulian 1Medan Tahun Ajaran 2017/2018. Metode penelitian yang digunakan adalah PTK, yang terdiri dari siklus I dan siklus II. Setelah data terkumpul, dzilakukan analisis pembelajaran melalui variasi pembelajaran. (1) Dari tes hasil belajar melalui variasi Pembelajaran di siklus I diperoleh 13 siswa yang tuntas $(68,42 \%)$ sedangkan 6 siswa $(31,58 \%)$ belum tuntas, dengan nilai rata-rata ketuntasan belajar passing atas $(76,27)$. Belum tercapai ketuntasan klasikal maka dilakukan kembali pembelajaran melalui variasi pembelajaran (2) dari tes hasil belajar II disiklus II diperoleh 17 siswa yang tuntas $(89,47 \%)$ sedangkan 2 siswa $(10,53 \%)$ belum tuntas, dengan nilai rata-rata ketuntasan belajar passing atas sebanyak $(81,54 \%)$. Maka sudah tercapai lah nilai klasikal $85 \%$ tersebut. Dalam hal ini dapat dilihat bahwa terjadi peningkatan $21 \%$ dari siklus I ke siklus II. Berdasarkan hasil analisis data, penelitian ini menyimpulkan bahwa melalui variasi pembelajaran dapat meningkatkan hasil belajar Passing atas Bola Voli Siswa Teknik Komputer Jaringan SMK Parulian 1 Medan Tahun 2018.
\end{abstract}

Kata kunci: Belajar, Passing Atas, Bolavoli

\section{ABSTRACT}

This research was conducted aimed at knowing how far the increase in learning outcomes Passing through learning variations in class XI Parulian 1Medan Vocational School 2017/2018 Academic Year. The research method used is PTK, which consists of cycle I and cycle II. After the data is collected, dzilakukan analysis of learning through variations in learning. (1) From the learning outcomes test through variations in Learning in the first cycle, 13 students were completed (68.42\%) while 6 students (31.58\%) were not completed, with an average passing grade of passing learning (76.27). Classical completeness has not yet been achieved so learning through learning variations (2) from learning outcomes II in cycle II is obtained by 17 students who complete (89.47\%) while 2 students $(10.53 \%)$ have not yet completed, with average completeness scores top passing learning (81, $54 \%)$. Then the $85 \%$ classical value has been reached. In this case it can be seen that there is a $21 \%$ increase from cycle I to cycle II. Based on the results of data analysis, this study concluded that through learning variations can improve learning outcomes Passing on Volleyball Ball Computer Engineering Students Network Medan Parulian 1 Vocational School in 2018.

Keywords: Study, Upper Passing, Volleyball

\section{PENDAHULUAN}

Pembangunan Nasional di bidang pendidikan merupakan upaya untuk mencerdaskan kehidupan bangsa dan meningkatkan kualitas manusia Indonesia dalam mewujudkan masyarakat yang adil dan makmur, serta memungkinkan para warganya mengembangkan dirinya dari segala aspek, baik jasmaniah maupun rohaniah. Pendidikan jasmani merupakan proses pendidikan seseorang sebagai perorangan maupun sebagai anggota masyarakat yang dilakukan secara sadar dan sistematik melalui berbagai kegiatan jasmani dalam rangka memperoleh peningkatan kemampuan dan keterampilan jasmani, pertumbuhan kecerdasan dan pembentukan watak. Olahraga merupakan bentuk-bentuk kegiatan jasmani yang terdapat didalam permainan, perlombaan dan kegiatan jasmani yang intensif dalam rangka 
memperoleh rekreasi, kemenangan dan prestasi optimal.

Permainan bola voli merupakan salah satu materi yang terdapat dalam kurikulum mata pelajaran pendidikan jasmani dan olahraga. Permainan bola voli kini telah mengalami perkembangan yang cukup pesat. Hal ini ditandai dengan banyaknya kejuaraan yang telah digelar, baik tingkat nasional maupun internasional. Semua lapisan masyarakat, mulai dari usia anak-anak hingga dewasa, baik pria maupun wanita telah mengenal permainan bola voli. Sebagai permainan yang telah memasyarakat, permainan bola voli memiliki peraturan serta teknik-teknik dasar yang sudah semestinya kuasai baik untuk kalangan pemula maupun kalangan profesional salah satunya adalah teknik passing.

Teknik passing merupakan salah satu dari teknik dasar permainan bola voli yang harus dikuasai dengan baik. Hal ini dapat membantu pemain dalam menghadapi permainan di lapangan. Passing atas merupakan salah satu passing yang sering digunakan oleh pemain bola voli untukmengumpan bola kepada teman satu regu dalam taktik pertahanan maupun penyerangan. Dalam taktik penyerangan passing atas digunakan sebagai satu cara untuk mempermudah rekan melakukan smash/spike daerah lawan. Dalam pembelajaran di sekolahpun masih banyak dijumpai siswa yangbelum bisa menguasai teknik passing atas.

Guru penjas dalam mengajarkan pembelajaran masih menggunakan gaya mengajar komando saja pada saat pembelajaran berlangsung, demikian kebebasan guru mengajar terhadap siswa sangat terbatas, hanya kepada mau tidaknya siswa mengikuti atau memenuhi perintah guru dengan sepenuh hati atau dengan kata lain dinyatakan bahwa siswa tidak mempunyai kebebasan untuk membuat keputusan. Siswa lebih cenderung mengikuti, sehingga efektifitas pembelajaran semua diatur oleh guru.

Dari Hasil observasi di sekolah Smk Parulian 1 Medan, yaitu terletak di Jalan Stadion teladan no.23 Medan Tanggal 9 Oktober 2017, permasalahan yang ditemukan peneliti setelah dilakukan observasi dan melihat hasil belajar siswa pada penguasaan teknik passing atas pada permainan bola voli sangat rendah sehingga peneliti berusaha untuk memperbaiki permasalahan yang di temukan dikelas ini. Kesalahan yang sering dilakukan siswa dalam pelaksanaan Passing atas adalah: posisi badan tidak dibungkukkan kedepan, kaki tidak ditekuk dan kaki dibuka sejajar dengan bahu, perkenaan bola ke tangan tidak tepat pada ujung-ujung jari, pada saat datangnya bola ke tangan gerakan tangan siswa pada saat mempassing kurang dapat dikuasai Peneliti melihat masih rendahnya siswa melakukan teknik passing atas dan mereka hanya melakukan gerakan bebas dalam artian mereka seperti bermain biasa tanpa memperhatikan seperti awalan, perkenaan dan lanjutan. Hal ini disebabkan karena kurangnya pengarahan dan pembinaan Guru terhadap siswa dan metode pembelajaran yang digunakan belum tepat, dengan pembelajaran yang tidak tepat tersebut membuat siswa cenderung diam, kurang aktif dan kurang bersemangat, karena kurangnya bentuk variasi pembelajaran passing atas bola voli yang diberikan oleh guru pendidikan jasmani pada saat pembelajaran berlangsung sehingga siswa cepat jenuh dan merasa bosan pada saat melakukan teknik passing atas bola voli. Guru pendidikan jasmani masih mengalami kesulitan dalam mengajar materi bola voli tersebut dikarenakan keterbatasan alat dan cara mengajar yang monoton membuat siswa cepat bosan. Sekolah hanya mempunyai 2 bola voli, yang Jumlahnya tidak sama dengan banyaknya siswa oleh karena itu siswa cepat bosan untuk menunggu giliranya melakukan teknik passing atas.

Menurut peneliti, masalah tersebut tidak boleh dibiarkan berkelanjutan. Guru pendidikan jasmani perlu lebih memberikan perhatian atau merespon gejala ini dan tidak menganggap hal ini sebagai hal yang biasa, apabila dibiarkan berlarut-larut dikuatirkan akan menurunkan prestasi belajar penjas siswa secara umum. Oleh karena itu diperlukan berbagai upaya yang dapat menunjang keberhasilan siswa dalam belajar. Yaitu upaya yang dilakukan dengan pendekatan belajar dengan pelajaran yang lebih bervariasi yang sesuai dan dapat meningkatkan hasil passing atas bola voli siswa, seperti passing atas berhadapan, passing atas dengan menggunakan formasi segitiga dan passing atas berkelompok yang akan membuat belajar siswa lebih menarik untuk mempelajarinya Sehingga hasil belajar siswa naik secara signifikan.

Tujuan penelitian yang diuraikan dalam rumusan masalah adalah untuk mengetahui Peningkatan Hasil Belajar Passing Atas Bola Voli Melalui Variasi Pembelajaran Pada Siswa Teknik Komputer Jaringan SMK 
Parulian 1 Medan Tahun 2018.

Hasil penelitian ini diharapkan dapat memberikan manfaat baik secara teoritis maupun secara praktis: Secara teoritis: (1) Penelitian ini diharapkan dapat bermanfaat untuk dijadikan sebagai sumber informasi dalam menjawab permasalahan-permasalahan yang terjadi dalam proses pembelajaran terutama dalam meningkatkan hasil belajar passing atas bola voli siswa Smk Parulian 1 Medan, (2) Selain itu penelitian ini diharapkan dapat bermanfaat sebagai bahan referensi dalam merancang metode pembelajaran dengan Variasi pembelajaran yang sesuai. Secara praktis: (1) Bagi guru untuk memperbaiki proses pembelajaran passing atas bola voli dan menciptakan suasana pembelajaran yang lebih menyenangkan, (2) Bagi siswa dapat meningkatkan hasil belajar passing atas, dan dengan variasi pembelajaran siswa lebih mudah mengatasi kesulitan belajar passing atas bola voli, (3) Bagi peneliti, menambah wawasan untuk mengembangkan pembelajaran yang lebih baik lagi terutama dalam hal passing atas bola voli, (4) Bagi peneliti lain yaitu dapat menjadi rujukan, sumber informasi dan bahan referensi penelitian selanjutnya agar bisa dikembangkan dalam materi-materi lainya.

Sudjana (2004: 37). Menyebutkan bahwa sebagian terbesar perkembnagn individu berlangsung melalui kegiatan belajar. Atau "belajar dapat diartikan sebagai suatu proses yang dilakukan oleh individu untuk memperoleh perubahan perilaku baru secara keseluruhan, sebagai hasil dari pengalaman individu itu sendiri dalam berinteraksi dengan lingkunganya". Sudjana (2004: 28) Hasil belajar adalah sebagai akibat dari proses belajarnya yang dilakukan oleh siswa harus semakin tinggi hasil belajar yang diperoleh siswa.

Permainan bola voli diciptakkan oleh William G Morgan pada tahun 1895 di Holyoke (Amerika bagian timur). William G Morgan adalah seorang pembina pendidikan jasmani pada Young Men Christian Association (YMCA). Permainan bola voli di Amerika sangat cepat perkembangnnya, sehingga tahun 1933 YMCA mengadakan kejuaran voli tingkat nasional. Muhajir (2004:30) menyatakan "permainan bola voli cukup dikenal di Indonesia. Bola voli dimainkan ditiap regu yang terdiri dari 6 pemain. Tiap regu berusaha menempatkan bola didaerah lawan agar mendapat angka (point). Regu yang pertama mencapai angka 25 adalah regu yang menang". Sabaruddin Yunis Bangun (2017: 2) Menyatakan Permainan bola voli adalah permainan yang dimainkan oleh dua regu yang berjumlah enam orang setiap regunya.

Dalam permainan bola voli terdapat beberapa teknik dasar dalam permainan bola voli yaitu passing, servis, smash, dan blocking. Salah satu teknik dasar yang harus dikuasai untuk dapat bermain bola voli dengan baik adalah teknik dasar passing. Teknik passing atas, merupakan teknik dasar permainan bolavoli yang mayoritas dipergunakan dalam permainan. Artinya lebih banyak dipergunakan dalam permainan. Bola yang berasal dari teman maupun lawan dapat dilakukan teknik passing atas. Passing atas saat menyajikan bola kepada teman seregunya yang selanjutnya diharapkan akan dapat dipergunakan untuk menyerang ke lapangan lawan". Aip Syarifuddin (1997: 69) menyatakan bahwa: "passing atas adalah cara pengambilan bola atau mengoper dari atas kepala dengan jari jari tangan diatas. Bola yang datang dari atas diambil dengan jari-jari tangan diatas, agak didepan kepala".

Bentuk latihan yang khusus untuk menunjang tercapainya aspek penentu serta kemampuan pemain dalam permainan bolavoli khusus teknik passing atas. Akan tetapi sering dijumpai bahwa para pemain bolavoli pada umumnya hanya diberikan latihan yang telah di dapati sebelumnya, tanpa memperhatikan latihan lainnya, yang lebih mengarah pada kemampuan passing atas dalam permainan bolavoli. Dalam teknik pelaksanaan passing atas, jari-jari tangan adalah kunci keberhasilan pemain untuk melakukan passing atas secara benar dan baik. Untuk hal tersebut dibutuhkan kemampuan seorang pemain agar dapat mengotomatisasikan gerakan.

Menurut M. Yunus (1992: 79) langkah-langkah melakukan passing atas adalah sebagai berikut: (1) Sikap Permulaan, ambil posisi normal yaitu: kedua kaki berdiri selebar bahu, berat badan menumpu pada telapak kaki bagian depan, lutut ditekuk dengan badan merendah tempat badan secepat mungkin di bawah bola, dengan kedatangan diangkat lebih tinggi dari dahi, dan jari-jari tangan terbuka lebar membentuk cekungan seperti setengah lingkaran, (2) Gerakan pelaksanaan, tepat saat bola berada diatas dan sedikit di depan dahi, lengan diluruskan dengan gerakan agak eksplosif untuk mendorong bola. Perkenaan bola pada permukaan jari ruas pertama dan kedua, dan 
yang dominan mendorong bola adalah ibu jari, jari telunjuk dan jari tengah. Pada waktu perkenaan dengan bola,jari-jari agak ditegangkan kemudian diikuti dengan gerakaan pergelangan tangan agar bola memantul dengan baik, (3) Gerakan lanjutan, Setelah bola memantul dengan baik, lannjutan dengan meluruskan lengan ke depan atas sebagai suatu gerakaan lanjutan, diikuti dengan memindahkan berat badan ke depan dengan kaki belakang melangkah ke depan dan segera mengambil sikap siap dan posisi normal. Passing atas merupakan salah satu teknik dasar bola voli yang memiliki pola gerakan yang cukup kompleks, jika dibandingkan dengan passing bawah. Tidak setiap siswa mampu melakukan passing atas dengan baik. Passing atas merupakan unsur yang terpenting dalam permainan bolavoli. Banyak perincian yang perlu diperhatikan sebelum siswa mampu melakukan proses gerak yang sangat rumit dalam passing atas.

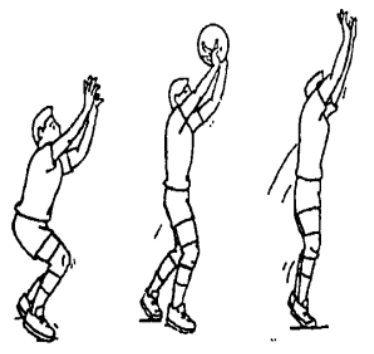

\section{Gambar 1. Tahap-tahap melakukan overhead volley}

Untuk mencapai pemahaman teknik dasar passing atas atau over head dengan baik maka diperlukan latihan yang teratur dan terukur juga harus memperhatikan kesalahan pada setiap melakukan passing atas untuk intropeksidiri sehingga dapat menguasai teknik passing atas atau overhead dalam permainan bola voli dengan baik. Kesalahan tersebut antara lain meliputi: (1) Tubuh tidak diarahkan sesuai dengan arah tujuan bola, voli terlalu cepat, (2) Bola dimainkan pada saat tubuh bergerak, voli kurang cermat karena gerakan tubuh pemain, (3) Lengan kurang lurus, (4) Pergelangan tangan terlalu kaku, voli kurang terkontrol, (5) Jari-jari terlalu kaku dan lurus, bola berputar di udara sesudah di voli, (6) Ibu jari dijulurkan ke depan, bola akan menyimpang kekanan dan ke kiri, (7) Kedua tangan terlalu jauh yang satu dengan yang lain, bola akan menyelinap di antara kedua tangan, (8) Gerakan-gerakan kaki, bagian bawah tubuh dan lengan yang kurang terkoordinasi dengan baik, (9) Timming yang kurang baik sehingga kontak dengan bola terlalu cepat atau sudah terlambat.

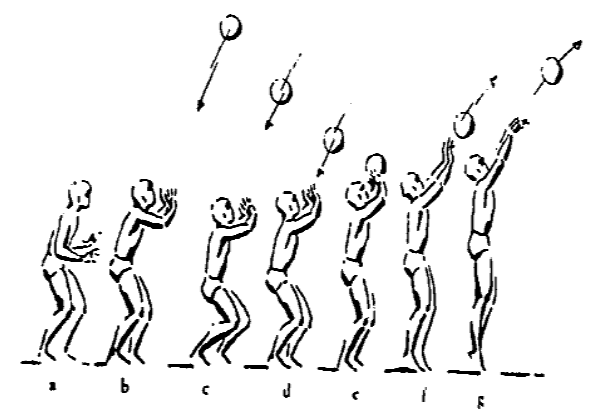

Gambar 2. Gaya sempurna melakukan passing atas

Passing atas mempunyai peran penting dalam permainan bola voli, karena Passing atas merupakan suatu teknik utama dalam permainan bola voli. Maka dari itu pada saat melakukan passing atas harus diperhatikan berbagai hal yaitu konsentrasi saat melakukan passing atas, berlatih dan menyesuaikan diri untuk menguasai bola, lihat dan pelajari diamana tempat menempatkan bola yang tepat, ketahui posisi lemah regu lawan. Teknik passing atas ini dapat dilakukan dengan baik apabila dilakukan dengan sungguh-sungguh.

Penerapan Passing atas dapat dilakukan dengan cara menyajikan bola atau mengoper bola menggunakan jari tangan kepada lawan atau langsung ke lapangan lawan, disamping itu passing atas yang baik akan mempengaruhi didalam pertandingan, tetapi hal ini lebih menonjol dalam pertandingan tingkat tinggi dibandingkan pada pertandingan yang lebih rendah.

Salah satu kemampuan dasar mengajar yang juga harus diakui oleh seorang guru adalah keterampilan dalam mengadakan variasi pembelajaran Keterampilan dalam mengadakan variasi pembelajaran tidak kalah penting dalam proses pembelajaran. Ahmad Sabri (2007: 142) menjelaskan bahwa "dalam konteks pembelajaran variasi diperlukan dengan tujuan agar perhatian siswa meningkat, memotivasi siswa, menjaga wibawa guru dan mendorong kelengkapan fasilitas pembelajaran". Penggunaan variasi menurut Ahmad Sabri (2010:95) yaitu untuk menimbulkan dan meningkatkan perhatian siswa pada aspek belajar mengajar yang relevan, untuk memberikan kesempatan bagi berkembangnya bakat ingi mengetahui dan menyelidiki pada siswa tentang hal hal yang baru dan untuk memberikan kesempatan untuk 
memperoleh cara menerima pelajaran yang disenangi".

Pengadaan variasi pembelajaran yang tepat dalam kegiatan belajar mengajar dapat memungkinkan guru untuk: (a) Menimbulkan dan meningkatkan partisipasi siswa terhadap kegiatatan-kegiatan belajar mengajar yang relevan, (b) Mewujudkan dengan baik kesempatan berkembangnya bakat dan motivasi dan rasa ingin tau tentng hal-hal yang baru, (c) Membentuk dan mengembangkan sikap positif siswa terhadap guru dan sekolah melalui berbagai cara untuk mengajar yang lebih hidup dan lingkungan belajar yang sama. (d) Memberikan kesempatan yang luas kepada siswa untuk mencoba cara yang lebih mudah bagi dirinya untuk menguasai bahan-bahan pembelajaran.

\section{METODE PENELITIAN}

Subjek dalam penelitian ini adalah seluruh siswa kelas XI-Teknik Komputer Jaringan SMK Parulian 1 Medan yang terdiri dari siswa putra putri sebanyak 19 orang. Penelitian ini menggunakan pendekatan PTK (Penelitian Tindakan Kelas), penelitian yang dilakukan bermaksud untuk menemukan informasi tentang pelaksanaan variasi pembelajaran yang disampaikan dengan penelitian tindakan kelas. Passing atas yang penelitian terapakan adalah sebagai berikut: (1) Passing atas berpasangan, (2) Passing atas variasi segitiga, (3) Passing atas bekelompok. Adapun desain penelitian adalah dengan 2 siklus sebagai berikut:

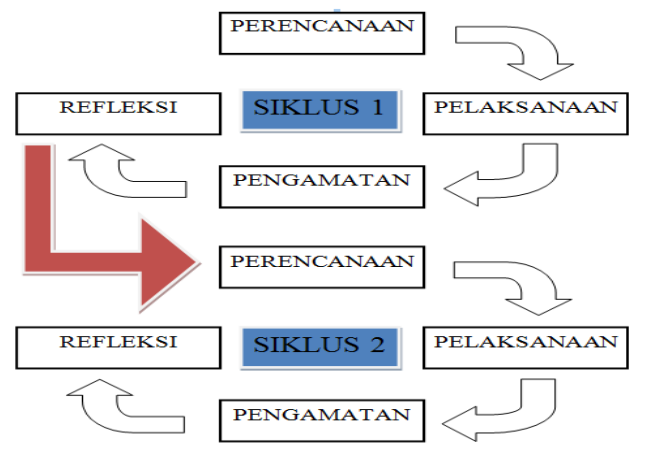

Gambar 3. Desain Penelitian Tindakan Kelas, Arikunto (2006: 6)

Teknik analisis data yang penulis gunakan dalam penelitian ini adalah teknik analisis data kuantitatif, dapat diketahui siswa yang belum belajar dan siswa yang sudah tuntas dalam belajar secara individu. Selanjutnya dapat juga diketahui apakah ketuntasan belajar siswa secara klasikal dapat tercapai, dilihat dari persentase siswa yang sudah tuntas dalam pembelajaran dapat di rumuskan sebagai berikut :

$$
\text { PKK }=\frac{\text { Banyak siswa yang } K K M}{\text { Banyak siswa keseluruhan }} \times 100 \%
$$

Keterangan: Persentase Ketuntasan Klasikal

Berdasarkan kriteria ketuntasan belajar, jika dikelas telah tercapai $85 \%$ yang telah mencapai persentase penilaian $\geq 70 \%$ maka ketuntasan klasikal telah tercapai, Suryo Subroto (1997: 129)

\section{HASIL \& PEMBAHASAN}

Penelitian ini dilaksanakan di SMK Parulian 1 Medan Tahun Ajaran 2017/2018. Penelitian ini dilaksanakan sesuai jadwal mata pelajaran di kelas XI Teknik Komputer Jaringan Tepatnya pada tanggal 02 Desember s/d 16 Desember 2017. Adapun deskripsi data penelitian yang diperoleh dapat dilihat pada tabel dibawah ini dimulai dari data awal, tes siklus I dan tes siklus II.

Tabel 1. Hasil perbandingan ketuntasan belajar secara keseluruhan

\begin{tabular}{cccc}
\hline No & Hasil Tes & $\begin{array}{c}\text { Jumlah } \\
\text { Siswa yang } \\
\text { Tuntas }\end{array}$ & $\begin{array}{c}\text { Jumlah } \\
\text { Siswa yang } \\
\text { Belum } \\
\text { Tuntas }\end{array}$ \\
\hline 1 & Data Awal & 4 & 15 \\
\hline 2 & Siklus I & 13 & 6 \\
\hline 3 & Siklus II & 17 & 2 \\
\hline
\end{tabular}

Pada data awal terlihat 4 orang yang mencapai ketuntasan belajar, sedangkan pada siklus I setelah mendapatkan perlakuan terjadi peningkatan sebanyak 9 orang yaitu dengan ketuntasan belajar sebanyak 13 orang. Penyebabnya adalah karena diberikan perlakuan dengan menggunakan variasi pembelajaran yang mengakibatkan siswa menjadi semangat dan tidak jenuh saat berlangsungnya proses belajar-mengajar. Masih ada kendala yang mengakibatkan siswa tidak tuntas diantaranya kurangnya rasa percaya diri dan malu pada teman sebaya nya. 


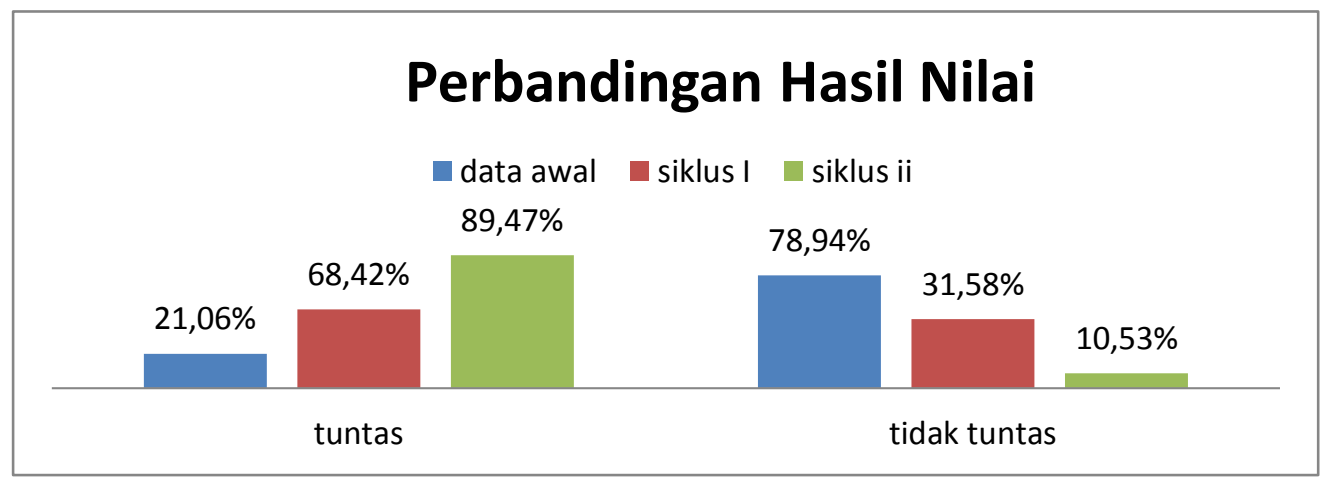

Gambar 4. Perbandingan ketuntasan hasil belajar siswa setiap siklus

Berdasarkan hasil data awal passing atas bola voli dapat dilihat bahwa kemampuan siswa dalam pembelajaran passing atas bola voli masih tergolong rendah. Dari 19 orang siswa yang menjadi subjek penelitian dalam penelitian ini, ternyata hanya 4 orang siswa $(21,06 \%)$ yang memiliki ketuntasan belajar, selebihnya 15 orang siswa $(78,94 \%)$ belum memiliki ketuntasan belajar.

Kemudian pada hasil tes siklus I ketuntasan belajar siswa meningkat menjadi 13 siswa $(68,42 \%)$ yang memiliki ketuntasan belajar, sedangkan 6 siswa $(31,58 \%)$ belum mencapai ketuntasan belajar. Pada hasil tes siklus II ketuntasan belajar siswa meningkat lagi menjadi 17 siswa $(89,47 \%)$ yang memiliki ketuntasan belajar, sedangkan selebihnya 2 siswa $(10,53 \%)$ belum mencapai ketuntasan belajar. Untuk hasil di siklus 2 teknik fase Sikap persiapan siswa yang mampu melakukan di setiap deskriptor berjumlah 63 indikator dari keseluruhan siswa, Untuk teknik fase Sikap Pelaksanaan siswa yang mampu Melakukan di setiap deskriptor berjumlah 57 indikator dari keseluruhan siswa, Untuk teknik fase sikap lanjutan siswa yang mampu melakukan di setiap indikator berjumlah 64 indikator dari keseluruhan siswa.

\section{Pelaksanaan Siklus I}

melakukandakan yang dilakukan adalah menggunakan variasi pembelajaran untuk meningkatkan ketuntasan hasil belajar siswa pada siswa kelas XI TKJ SMK Parulian 1 Medan Tahun Ajaran 2017/2018.

Pada tahap ini kegiatan yang dilakukan adalah merencanakan tindakan berupa membuat Rencana Pelaksanaan Pembelajaran (RPP) yang disesuaikan dengan kesulitan yang dialami siswa dengan membuat kegiatan variasi pembelajaran. Kegiatan lain yang dilakukan adalah membuat lembar portofolio untuk melihat bagaimana kondisi belajar mengajar dikelas dan membuat Tes Hasil Belajar.

Tujuan dari siklus I yaitu menerapkan variasi pembelajaran untuk meningkatkan hasil belajar passing atas siswa pada permainan bola voli. Tindakan yang dilakukan peneliti sebagai berikut: Merancang pembelajaran yang akan diterapkan, membuat Rencana Pelaksanaan Pembelajaran, yang sesuai dengan standart kompetensi, kompetensi dasar dan indikatornya, menarik minat siswa pada saat mengikuti ke 3 variasi pembelajaran, membuat Skenario sikap Awalan, sikap pelaksanaan dan sikap lanjutan, menyiapkan lembar observasi guru dan siswa, menyiapkan lembar kriteria yang digunakan dalam pembelajaran, menyiapkan lembar penilaian, menyiapkan peralatan.

Dalam proses belajar mengajar pada siklus I, dari hasil pengamatan terlihat masih ada kekurangan. Diantaranya masih ada siswa yang belum memahami gerakan passing atas bola voli yang benar. Beberapa siswa masih ada yang melakukan passing atas bola voli dengan posisi jari rapat. Beberapa siswa masih ada yang melakukan passing atas bola voli kaki tidak dibuka selebar bahu. Walaupun ada kekurangan-kekurangan dalam proses belajar mengajar selama siklus I, terjadi juga peningkatan hasil belajar siswa dibandingkan dengan sebelum tindakan dilakukan.

Gambar 5. Perbandingan ketuntasan belajar pada siklus I

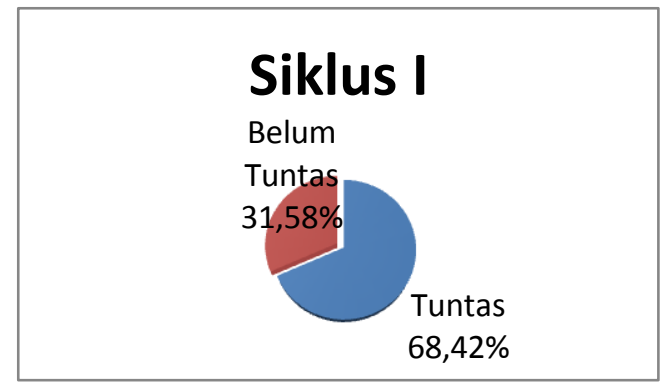


Secara umum berdasarkan hasil observasi melalui variasi pembelajaran menunjukkan hasil yang lebih baik pada siswa dalam mengetahui gerakan passing atas bola voli namun belum mencapai ketuntasan secara klasikal. Adapun hasil belajar siklus I dapat dilihat pada gambar di samping kiri ini:

Berdasarkan hasil observasi perlu diadakan perbaikan terhadap kesalahan dan kesulitan yang dialami siswa dalam proses pembelajaran: Kelebihan (1) Pembelajaran menjadi lebih aktif dan menyenangkan, (2) Minat siswa ingin melakukan passing atas menjadi meningkat. Kekurangan: (1) Dari segi alokasi waktu masih terdapat kekurangan dalam mengatur waktu pembelajaran, (2) Variasi pembelajaran menjadi terganggu karena banyak siswa yang kurang serius dalam melakukan variasi pembelajaran, (3) Kondisikondisi anak yang belum mampu melakukan pembelajaran di tiap deskriptor. seperti tidak mengambil sikap siap, kedua kaki tidak dibuka selebar bahu, lutut tidak ditekuk dan sikap badan tinggi, kedua lengan tidak diangkat diatas kepala melainkan didepan kepala dan lengan tersebut pun tidak ditekuk. Solusi: (1) Guru harus jelih didalam mengalokasikan waktu di proses belajar mengajar berlangsung, (2) Guru harus menarik minat belajar passing atas bola voli siswa seperti memberi arahan yang jelas tentang posisi passing atas yang benar agar siswa bisa lebih serius dalam melakukan tiap-tiap variasi pembelajaran, (3) Guru menjelaskan disetiap deskriptor kepada anak agar anak bisa melakukan gerakan yang benar sesuai arahan di deskriptor, (4) Bagi siswa yang belum tuntas, waktu pada kegiatan inti diperbanyak agar bisa mengulanginya dan bisa melakukan passing atas bola voli.

Selanjutnya hasil belajar siklus I ini digunakan sebagai acuan dalam memberikan tindakan pada siklus II. Sehingga pada pelaksanaan tindakan siklus II dapat mengatasi kesulitan dalam pembelajaran passing atas bola voli.

\section{Pelaksanaan Siklus II}

Pada tahap perencanaan tindakan II disusun untuk mengatasi permasalahan yang dialami siswa pada siklus I. Adapun perencanaan yang akan dibahas sama seperti pada siklus I, guru tetap membuat RPP dan perangkat pembelajaran, waktu menjadi 70 menit. Pada tahap siklus II ini, peneliti tetap menggunakan variasi pembelajaran, dalam pelaksanaanya guru memperbanyak memberikan motivasi kepada siswa. Hal ini bertujuan agar siswa lebih aktif dan bersemangat dalam pembelajaran. Dalam pembelajaran siklus II ini, guru lebih banyak memberikan umpan balik kepada siswa, guru berkonsentrasi untuk mengawasi siswa agar benar-benar melakukan passing atas berdasarkan lembar kriteria. Guru melakukan penjelasan tentang pelaksanaan fase persiapan, pelaksanaan dan Lanjutan. Pada tahap ini kegiatan yang dilakukan adalah: Membariskan siswa, memeriksa kehadiran siswa dan berdoa, menjelaskan materi proses belajar yang benar, siswa melaksanakan pemanasan, Guru melaksanakan kegiatan pembelajaran materi passing atas bola voli dengan menggunakan ke 3 variasi pembelajaran tersebut, memanfaatkan waktu yang di lebihkan dari siklus I ke siklus II agar siswa bisa lebih banyak mengulanginya, menarik minat siswa agar serius dalam mengikuti pembelajaran, membuat Skenario sikap Awalan, sikap pelaksanaan dan sikap lanjutan yang tepat, guru membagi siswa menjadi 2 kelompok. Untuk melakukan variasi pembelajaran pertama yaitu passing atas berpasangan, guru membagi siswa menjadi 4 kelompok, untuk melakukan variasi pembelajaran kedua yaitu passing atas segitiga memasukan bola voli, guru membagi siswa menjadi 4 kelompok. untuk melakukan variasi pembelajaran.

ketiga yaitu passing atas berkelompok, guru memberikan bimbingan dan motivasi setelah selesai pembelajaran, guru menutup pembelajaran dengan melakukan pendinginan dan doa.

Berdasarkan hasil penelitian pelaksanaan tindakan pada siklus II mengalami keunggulan dibandingkan siklus I. Dimana hasil belajar siklus I dan siklus II dapat dilihat terjadi peningkatan hasil belajar secara individu maupun klasikal. Pada tes hasil belajar I terdapat $68,42 \%$ siswa yang mencapai ketuntasan belajar, sedangkan pada siklus II terdapat $89,47 \%$ yang telah mencapai ketuntasan belajar. Sehingga hasil belajar siklus I ke siklua II naik sebanyak $21 \%$. Maka dapat disimpulkan pembelajaran passing atas melalui variasi pembelajaran pada tes hasil belajar siklus I dan siklus II mengalami peningkatan hasil belajar baik secara individu maupun klasikal. Akan tetapi masih ada beberapa siswa yang belum memperoleh ketuntasan belajar per individu. Untuk mengatasi permasalahan tersebut dikembalikan kepada guru pendidikan jasmani untuk meningkatkan hasil belajar mereka dengan memberikan motivasi dan memerintahkan 
siswa agar banyak berlatih diluar jam pelajaran. Adapun hasil belajar siklus II dapat dilihat pada gambar di bawah ini:

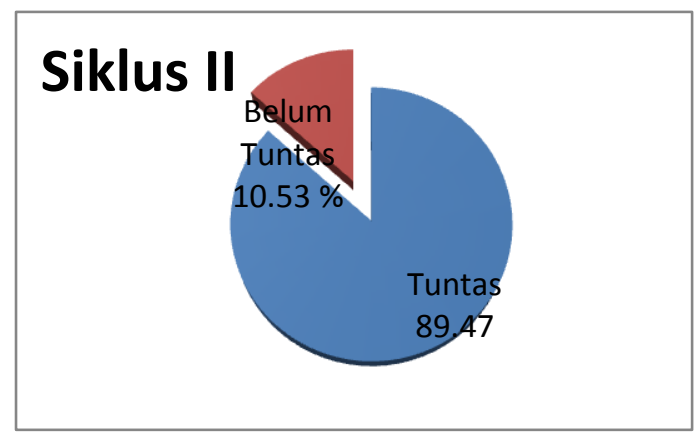

Gambar 6. Perbandingan ketuntasan belajar pada siklus

Siswa yang tuntas adalah sebanyak 17 orang dan yang belum tuntas sebanyak 2 orang. Kelemahan rata-rata di siklus ini di sikap pelaksanaan seperti posisi kaki tidak membentuk 45 derajat, bola tidak tepat berada diatas kepala dan lengan tidak di tekuk, arah pandangan tidak tertuju ke arah bola, arah bola tidak sesuai dengan yang diinginkan.

Berdasarkan hasil observasi perlu diadakan perbaikan terhadap kesalahan dan kesulitan yang dialami siswa dalam proses pembelajaran: (1) Kesulitan yang sering dihadapi seperti posisi kaki tidak membentuk 45 derajat, bola tidak tepat berada diatas kepala dan lengan tidak di tekuk, arah pandangan tidak tertuju ke arah bola, arah bola tidak sesuai dengan yang di inginkan, (2) Bagi 2 orang siswa yang belum bisa melakukan passing atas bola voli yang benar, maka siswanya akan dibimbing guru nya sesudah penelitian ini.

Dari analisis data yang telah dilakukan dapat disimpulkan bahwa dengan penerapan variasi pembelajaran dan modifikasi alat, dapat memberikan pengaruh serta meningkatkan hasil belajar passing atas bola voli. Dimana terlihat hasil belajar siswa dari tes hasil belajar siklus I dapat meningkatkan hasil belajar siswa pada materi passing atas bola voli. Hasil tes siklus I siswa yang mencapai ketuntasan 13 orang $(68,42$,$) dan 6$ orang $(31,58 \%)$ belum mencapai ketuntasan. Dimana pada tes hasil belajar siklus I didapat hasil penelitian belum memenuhi kriteria ketuntasan secara klasikal yang diharapkan yaitu $85 \%$. Hal ini dikarenakan beberapa faktor siswa tersebut belum bisa mencapai tingkat ketuntasan belajar karena pada sikap gerakan sikap persiapan masih banyak siswa yang sulit untuk melakukan passing atas bola voli. Untuk itu selanjutnya perlu diadakan perbaikan pada tindakan pada siklus II.

Kemudian pada pembelajaran di siklus II dapat dilihat bahwa telah terjadi peningkatan aktifitas siswa dari siklus sebelumnya yaitu pada saat melakukan sikap persiapan, sikap pelaksanaan, dan sikap lanjutan. Hasil tes pada siklus II menunjukkan siswa yang tuntas sebanyak 17 orang $(89,47 \%)$ dan yang belum tuntas 2 orang $(10,53 \%)$. Pada siklus II diperoleh penigkatan ketuntasan belajar klasikal $85 \%$ berarti terlihat ada peningkatan dari siklus I ke siklus II. Namun masih ada beberapa siswa yang belum memperoleh ketuntasan belajar per individu walaupun nilai yang diperoleh sudah meningkat dibandingkan pada siklus I. Dan untuk 2 orang siswa yang belum tuntas di siklus II tersebut dikembalikan kepada guru pendidikan jasmani sekolah untuk dibimbing dan dan arahkan ke teknik passing atas yang benar untuk meningkatkan hasil belajar siswa tersebut. Dan salah satu faktor yang dapat mendukung keberhasilan tersebut adalah penggunaan variasi pembelajaran.

Hal ini juga berlaku untuk mata pelajaran pendidikan jasmani, seperti yang telah diuraikan sebelumnya bahwa masalah yang selama ini dialami dalam pembelajaran passing atas bola voli adalah kurangnya minat dan perhatian siswa saat mengikuti proses pembelajaran. Selain itu, kebanyakan siswa tidak serius dan cepat merasa bosan dalam proses pembelajaran sehingga pada akhirnya hasil belajar yang diperoleh siswa masih rendah.

Oleh karena itu diperlukan suatu konsep pembelajaran yang dapat mendukung keberhasilan siswa, yaitu salah satunya pembelajaran melalui variasi pembelajaran. Dalam pembelajaran ini siswa diajarkan untuk aktif dalam pembelajaran. Siswa dapat memperbaiki kesalahan yang dilakukan pada pertemua sebelumnya di pertemuan selanjutnya.

KESIMPULAN \& SARAN
Berdasarkan hasil penelitian dan
pembahasan disimpulkan bahwa dengan
menggunakan variasi pembelajaran dapat
meningkatkan hasil belajar passing atas bola
voli pada siswa kelas XI Teknik Komputer
Jaringan SMK Parulian 1 Medan Tahun Ajaran
2017/2018.




\section{DAFTAR PUSTAKA}

Ahmadi Nuril. 2007. Olahraga Bola Voli. Surakarta: Era Pustaka Utama.

Ahmad Sabri. 2010. Strategi Belajar Mengajar. Ciputat: Quantum Teaching. Arikunto. 2006. Penelitian Tindakan Kelas. Jakarta: Bumi Aksara.

Bangun, Sabaruddin Yunis. 2017. "Resiprokal Menggunakan Simpai Memperbaiki Belajar Passing Atas Bola Voli”. Journal Sport Science and Education: Volume:2, Edisi: 1: 20-24.

Muhajir, 2004. Pendidikan Jasmani, Olahraga dan Kesehatan Jilid1. Jakarta: Erlangga.

Sudjana. 2004. Penilaian Hasil Belajar Mengajar. Bandung: Remaja Rosdakarya Dikti.

Syarifuddin Aip, Muhadi. 1991. Pokok-pokok Pengembangan Program Pembelajaran Pendidikan Jasmani. Jakarta: Depdikbud.

Yunus, M. 1992. Bola Voli Olahraga Pilihan. Jakarta: Depdikbud Direktorat Jenderal Tinggi. 